University of Nebraska - Lincoln

DigitalCommons@University of Nebraska - Lincoln

Sociology Department, Faculty Publications

Sociology, Department of

2005

\title{
Education and Churchgoing Protestants' Views of Highly Politicized Christianity
}

Philip Schwadel

University of Nebraska-Lincoln, pschwadel2@unl.edu

Follow this and additional works at: https://digitalcommons.unl.edu/sociologyfacpub

Part of the Sociology Commons

Schwadel, Philip, "Education and Churchgoing Protestants' Views of Highly Politicized Christianity" (2005). Sociology Department, Faculty Publications. 81.

https://digitalcommons.unl.edu/sociologyfacpub/81

This Article is brought to you for free and open access by the Sociology, Department of at DigitalCommons@University of Nebraska - Lincoln. It has been accepted for inclusion in Sociology Department, Faculty Publications by an authorized administrator of DigitalCommons@University of Nebraska - Lincoln. 


\title{
EDUCATION AND CHURCHGOING PROTESTANTS' VIEWS OF HIGHLY POLITICIZED CHRISTIANITY
}

\author{
PHILIP SCHWADEL \\ UNIVERSITY OF NEBRASKA, LINCOLN
}

REVIEW OF RELIGIOUS RESEARCH 2005, VOLUME 47:2, PAGES 150-161

\begin{abstract}
Many churchgoing Protestants support a highly political role for the Christian religion, endorsing Christian ideals shaping public policy. Highly educated Protestants' emphasis on individualism and protecting civil liberties, however, can encourage a distrust of highly politicized Christianity. Specifically, college and graduate school educated Protestants often want to avoid forcing the Christian religion on secular society. Regression results from the 1996 Religious Identity and Influence Survey show that, among churchgoing Protestants, education is strongly and negatively correlated with supporting laws based on Christian doctrines. Highly educated Protestants are also less likely than high school educated Protestants to advocate Christians attempting to change society to reflect God's will, particularly because they feel they should not impose the Christian religion on society. With debates over issues such as same-sex marriage and the use of "under God" in the Pledge of Allegiance, Protestants' views of the proper relationship between Christianity and politics will help shape future policy decisions; and highly educated Protestants'views will be increasingly important as college education becomes the norm in the Protestant community. The results provide insights into the religious privatization of highly educated churchgoing Protestants in the United States as well as supporting the notion that with increased education comes at least partial support for one aspect of secularization-desacralization, or the separation of religion from other primary institutions, especially the state.
\end{abstract}

\section{INTRODUCTION}

$\mathrm{R}$ ecent political headlines focusing on issues such as same-sex marriage, government funding of faith-based charities, and the words "under God" in the Pledge of Allegiance highlight the role of religion, and particularly Christianity, in the political arena. Political theorists have repeatedly debated the proper role of religion in politics (e.g. Audi and Wolterstorff 1997). Many philosophers, such as John Rawls (1993), support restrictions on religion's public role, criticizing political decisions influenced by religious ideals and fearing the ensuing cultural wars that accompany politicized religion. On the other hand, some say it is undemocratic to limit the public role of religion, suggesting that religion plays a positive role as a mediating institution (e.g. Carter 1993). With an ongoing academic debate about the role of religion in politics, we must also ask what the members of the majority religion, Protestantism, think about religion affecting political decisions, and specifically their views of the relationship between Christianity and U.S. politics. Further- 


\section{Education and Churchgoing Protestants'Views}

more, we must ask what factors affect Protestants' views of the politicization of Christianity.

Religious organizations are powerful forces of political and social mobilization (Beckford 1985), and in recent years there has been an increase in religious politicization (Herman 2001; Beyer 1994). No longer content to merely sway people's opinions and values, religious organizations are increasingly taking direct social and political action (Billings and Scott 1994). The politicization of Christianity in the U.S. is probably most evident in the recent deprivatization of evangelical Christians. In the last few decades evangelical Christians have waged political battles over abortion, sexual orientation, and religion in the schools; they had evangelical political icons such as Jimmy Carter and Ronald Reagan; and they had Christian political organizations like the Moral Majority (Regnerus and Smith 1998).

As Christian organizations become more directly involved in the political process, Protestants are also becoming more highly educated; and higher education is associated with greater support for individualism, protecting civil liberties, and aversion to being under the authority of others, including religious authority. Universities stress individuality and freedom of thought (Dewey 1959), traits that do not mesh well with compliance to authority. Americans with low levels of education are socialized to obey authority, whereas those with high levels of education are socialized to be self-directed, curious, individualistic, and non-conformist (Gilbert and Kahl 1987; Kohn and Schooler 1969). "The college experience, particularly at the better colleges, stimulates free inquiry, encourages the questioning of dogma, [and] undermines the force of tradition and authority" (Caplovitz and Sherrow 1977: 127). While the highly educated are often part of the authority structure, they tend not to acquiesce to authority (Fox et al. 1977; Sumner 1997).' Moreover, with increased education often comes a greater commitment to defending civil liberties and opposing repression of any kind (Hall, Rodeghier, and Useem 1986). The aversion to obeying authority among the college and graduate school educated suggests that they could be wary of religious authorities that attempt to control people's lives by enforcing Christian doctrines through political means.

Although many churchgoing Protestants support a highly politicized form of Christianity, this may change as more Protestants attend college and obtain advanced degrees. Religious organizations hold authority over their members and sometimes seek to exert control over non-members through political means. The emphasis on individuality and freedom from authority that is common among the college-educated may influence highly educated Protestants' views of the politicization of Christianity by raising questions about the repercussions of highly politicized religious authority. Churchgoing Protestants with a college degree may agree with the political viewpoint of their churches, but they are often uncomfortable with highly politicized Christianity or with the Christian religion imposing itself on society through political means. The increase in the politicization of Christianity has, in the U.S., led to increased tensions in church-state relations and also brought the accompanying fear that religious organizations will impose their worldviews on others (Hammond 2000; Robbins 1993).

While religious organizations have become more politically involved over the least few decades, religion has also become more privatized or more individualistic in the United States; particularly for highly educated Christians and mainline Protestants (Bellah et al. 1985; Regnerus and Smith 1998; Roof and McKinney 1987; Wuthnow 1988). Americans are certainly not antagonistic towards religion, but they are increasingly placing religious authority within the individual rather than within a religious institution. This is especially true of the more highly educated. For instance, Greer and Roof (1992) demonstrate that edu- 
cation positively affects religious privatization in terms of supporting individual forms of religion over formal church doctrine. Additionally, Regnerus and Smith (1998) note that education has a positive effect on the view that religion is a private matter rather than a public matter. This article extends research on education and religious privatization by showing the effects of education on a specific case of privatization-the distrust of highly politicized Christianity. Just as the college-educated often view religion as a private matter and support individual forms of religion over formal church doctrine, college-educated Christians should also be suspicious of highly politicized forms of Christianity that may result in forcing Christian ideals on secular society. The remainder of this article demonstrates that college and graduate school educated churchgoing Protestants are more distrustful of highly politicized Christianity than are less-educated churchgoing Protestants. Many college and graduate school educated Protestants are concerned that Christian organizations may be forcing the Christian religion on Christians and non-Christians alike.

\section{DATA AND METHODS}

The 1996 Religious Identity and Influence survey (RII) provides the measures needed to examine the effects of education on churchgoing Protestants' views of the politicization of Christianity. ${ }^{2}$ The sample is limited to churchgoing Protestants, since non-churchgoers may harbor ill feelings towards religion, thereby confounding distrust of highly politicized Christianity with distrust of religion in general. The RII data are a random sample of 2,591 noninstitutionalized U.S. adults. The RII telephone survey used randomly dialed U.S. phone numbers, excluding Alaska and Hawaii, employed in-home randomization methods, and was administered from January through March of $1996 .{ }^{3}$ To assure an appropriate number of respondents in various denominations, the survey contains an oversample of churchgoing Protestants. Respondents who, first, identified themselves as Protestant or belong to a Protestant denomination and, second, attend church at least twice a month and/or say faith is "extremely important" to their lives are considered churchgoing Protestants and, therefore, eligible for the oversample and included in this analysis. Two thousand and eighty-seven of the RII respondents are churchgoing Protestants (see Smith 1998 for more information on the RII data). This article examines the effects of education on (1) the view that Christian morality should be law, (2) the view that Christians should try to change society to reflect God's will, and (3) the view that Christians should not try to change society to reflect God's will because Christians should not impose their religion on American society.

Dummy variables for various levels of education are the primary independent variables (see Table 1 for descriptive statistics). There are dummy variables for those with less than a high school degree, a degree from a vocational or technical school, some college, a college degree, and any graduate school, with high school graduates being the reference category. Dummy variables, opposed to a continuous measure of education such as years of schooling, highlight where in the educational continuum variations in views of the politicization of Christianity occur.

Binary logistic regressions are employed in the following analyses. Binary logistic regressions compute the logged odds change in the dichotomous dependent variable for each one unit increase in the independent variables (Menard 1995). In this case, logistic regressions show the effects of education on the odds that churchgoing Protestants support various measures of the politicization of Christianity. Control variables are added to the models to assure that the effects of education are not clouded by individual or religious group variations. 
Education and Churchgoing Protestants' Views

Table 1.

Descriptive Statistics

\begin{tabular}{|c|c|c|c|c|}
\hline & Mean & Minimum & Maximum & $\mathrm{N}$ \\
\hline \multicolumn{5}{|l|}{ DEPENDENT VARIABLES } \\
\hline \multicolumn{5}{|l|}{ Christians Should'Be Trying To Change } \\
\hline Society To Better Reflect God's Will & 0.86 & 0 & 1 & 1,710 \\
\hline \multicolumn{5}{|l|}{ Christians Should Not Try To Impose Their } \\
\hline Religion On Others & 0.72 & 0 & 1 & 229 \\
\hline \multicolumn{5}{|l|}{ EDUCATION } \\
\hline Less than High School & 0.06 & 0 & 1 & 1,797 \\
\hline High School Graduate & 0.26 & 0 & 1 & 1,797 \\
\hline Vocational/Technical Degree & 0.07 & 0 & 1 & 1,797 \\
\hline Some College & 0.27 & 0 & 1 & 1,797 \\
\hline College Graduate & 0.21 & 0 & 1 & 1,797 \\
\hline Any Graduate School & 0.14 & 0 & 1 & 1,797 \\
\hline \multicolumn{5}{|l|}{ DENOMINATION } \\
\hline Conservative Protestant & 0.57 & 0 & 1 & 1,797 \\
\hline Mainline Protestant & 0.33 & 0 & 1 & 1,797 \\
\hline Black Protestant & 0.09 & 0 & 1 & 1,797 \\
\hline Other Protestant & 0.01 & 0 & 1 & 1,797 \\
\hline \multicolumn{5}{|l|}{ RELIGIOUS ID \& CHURCH ACTIVITY } \\
\hline Fundamentalist or Evangelical & 0.56 & 0 & 1 & 1,797 \\
\hline Church Attendance & 3.47 & 1 & 4 & 1,797 \\
\hline \multicolumn{5}{|l|}{ DEMOGRAPHIC VARIABLES } \\
\hline Marital Status & 1.85 & 1 & 5 & 1,797 \\
\hline Children & 0.81 & 0 & 1 & 1,797 \\
\hline Male & 0.36 & 0 & 1 & 1,797 \\
\hline Age & 46.57 & 17 & 96 & 1,797 \\
\hline Father's Education & 2.39 & 1 & 6 & 1,797 \\
\hline
\end{tabular}

Descriptive statistics weighted by household size

Dummy variables for those who are affiliated with a conservative denomination, an AfricanAmerican denomination, and other Protestant denominations control for denomination type, with mainline Protestant affiliation being the reference category. ${ }^{4}$ As Table 1 shows, $57 \%$ of the churchgoing Protestants in the RII sample are adherents of conservative denominations, $33 \%$ are adherents of mainline denominations, $9 \%$ are adherents of historically black Protestant denominations, and only $1 \%$ are adherents of other Protestant denominations. A dummy variable for those who identify themselves as either evangelical or fundamentalist Christians (56\% of the sample) and a measure of the frequency of church attendance control for religious orthodoxy and church activity. ${ }^{5}$ Basic demographics (age, sex, marital status, children, and father's education) control for variations in respondents' backgrounds. ${ }^{6}$ 


\section{RESULTS}

The first dependent variable is a direct measure of how churchgoing Protestants feel about highly politicized Christianity, specifically Christianity influencing the law. The RII survey asked respondents if they "think that Christian morality should be the law of the land, even though not all Americans are Christians?" About one-half of churchgoing Protestants say that Christian morality should be the law. Logistic regressions demonstrate that education has a negative, fairly linear effect on the view that Christian morality should be the law (Table 2). Churchgoing Protestants with more than a high school education are less likely than those with only a high school degree or no high school degree to say that Christian morality should be the law. The odds ratios provide the increase or decrease in odds by level of education, compared to those with a high school degree. All else being equal, the odds for a Protestant with a college degree agreeing that Christian morality should be the law is almost $44 \%$ lower than the odds for a Protestant with only a high school education (Model 2). Additionally, the odds for a Protestant with any graduate school education is almost $58 \%$ less than the odds for a high school graduate (Model 2). Fundamentalist or evangelical identification, church attendance, and denominational affiliation have fairly strong effects on the view that Christian morality should be the law. For instance, $60 \%$ of Protestants that are affiliated with conservative denominations and $32 \%$ of Protestants that are affiliated with mainline denominations say Christian morality should be the law (based on cross-tabs, not shown in table). Nevertheless, the effects of education on the view that Christian morality should be the law do not appear to be due to these other factors. Comparing the first and second models shows that the negative effects of education on the view that Christian morality should be law are only slightly reduced when denominational affiliation, fundamentalist or evangelical identification, church attendance, and demographic variables are included in the model. Both models 1 and 2 are fairly strong models, with Log Likelihoods that are significantly reduced from the null model and large Chi-Square statistics. Education's strong, negative effect on the view that Christian morality should be the law suggests that college and graduate school educated churchgoing Protestants are somewhat distrustful of highly politicized Christianity; and this effect holds true for both evangelical and fundamentalist Protestants and those who attend church on a regular basis.

The second regression analysis explores the effects of education on churchgoing Protestants' views that "Christians should be trying to change'American society to better reflect God's will." About $86 \%$ of churchgoing Protestants agreed with this statement. This item does not specify that the law should be changed to reflect specifically Christian doctrines, which is probably why more respondents reply positively to it than to the previous variable (only about one-half of respondents say Christian morality should be the law). The results show that highly educated Protestants, both the college and graduate school educated, are less likely than high school educated Protestants to say that Christians should be trying to change American society to better reflect God's will (Table 3). All else being equal, the odds of supporting Christian's changing society to reflect God's will are almost $40 \%$ lower for a college educated Protestant than for a high school educated Protestant (Model 2). Similarly, the odds of supporting Christians changing the world to reflect God's will are about $40 \%$ lower for a graduate school educated Protestant than for a high school educated Protestant (Model 2). While church attendance, fundamentalist or evangelical identification, and denominational affiliation are all strongly related to the view that Christians should try to change society to reflect God's will, the negative effects of college and graduate school education 
Table 2.

Binary Logistic Regressions Of The View That Christian Morality Should Be The Law Of The Land

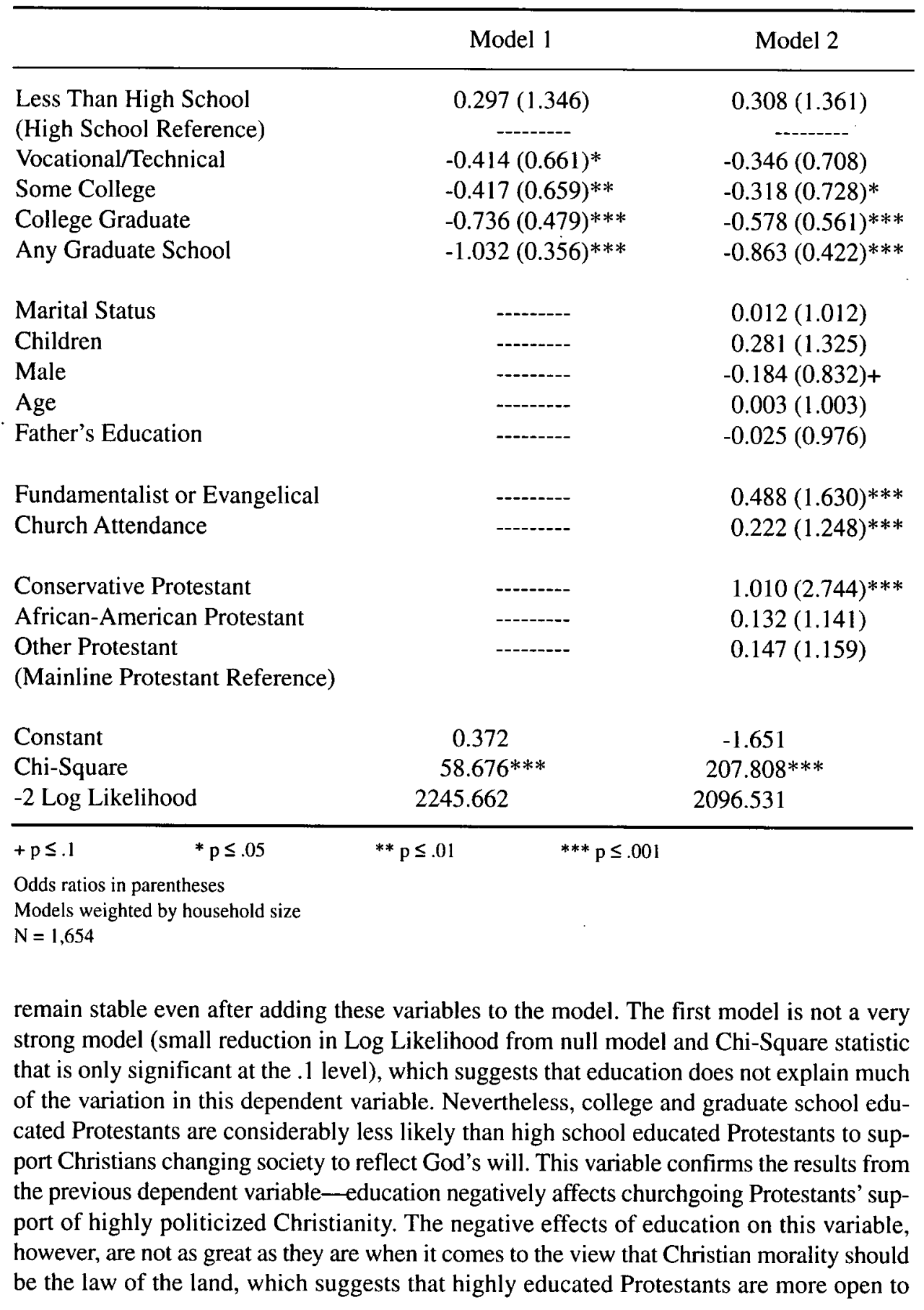


Table 3.

Binary Logistic Regressions Of The View That

Christians Should Be Trying To Change American Society

To Better Reflect God's Will

\begin{tabular}{|c|c|c|}
\hline & Model 1 & Model 2 \\
\hline Less Than High School & $-0.280(0.756)$ & $-0.223(0.801)$ \\
\hline (High School Reference) & -....... & -.......- \\
\hline Vocational/Technical & $0.099(1.104)$ & $0.193(1.213)$ \\
\hline Some College & $-0.161(0.851)$ & $-0.144(0.866)$ \\
\hline College Graduate & $-0.497(0.608)^{*}$ & $-0.497(0.608)^{*}$ \\
\hline Any Graduate School & $-0.534(0.586)^{*}$ & $-0.512(0.599)^{*}$ \\
\hline Marital Status & ----.--- & $-0.155(0.857)^{*}$ \\
\hline Children & --------- & $-0.291(0.748)$ \\
\hline Male & -..-..-- & $-0.312(0.732)^{*}$ \\
\hline Age & --------- & $0.004(1.004)$ \\
\hline Father's Education & --------- & $0.121(1.129)^{*}$ \\
\hline Fundamentalist or Evangelical & -------- & $0.666(1.947)^{* * *}$ \\
\hline Church Attendance & -.--..-.- & $0.360(1.434)^{* * *}$ \\
\hline Conservative Protestant & -----.-- & $0.847(2.333)^{* * *}$ \\
\hline African-American Protestant & -------- & $0.195(1.216)$ \\
\hline $\begin{array}{l}\text { Other Protestant } \\
\text { (Mainline Protestant Reference) }\end{array}$ & -.---.-- & $-0.064(0.938)$ \\
\hline Constant & 2.037 & 0.217 \\
\hline Chi-Square & $10.671+$ & $116.901 * * *$ \\
\hline -2 Log Likelihood & 1398.552 & 1292.322 \\
\hline
\end{tabular}

$+\mathrm{p} \leq .1 \quad * \mathrm{p} \leq .05 \quad * * \mathrm{p} \leq .01 \quad * * * \mathrm{p} \leq .001$

Odds ratios in parentheses

Models weighted by household size

$\mathrm{N}=1,710$

changing "American society to better reflect God's will" than to actually changing the law to reflect Christian doctrines.

I proposed that concern with Christianity forcing itself on secular society is a key component of college and graduate school educated Protestants' distrust of highly politicized Christianity. The RII data permit a further test of this hypothesis but with only a small subsample of the respondents. The previous dependent variable demonstrates that college and graduate school educated Protestants are less likely than high school educated Protestants to "think Christians should be trying to change American society to better reflect God's will." The RII data have a series of follow-up questions for respondents who said Christians should 
not be trying to change society (about $14 \%$ of churchgoing Protestant respondents). In addition to other questions, these respondents were asked if they "think Christians should not be trying to change society [because] Christians should not be trying to impose their religion on American society." Although only $14 \%$ of the respondents were asked this question, it is instructive to think about why these people believe Christians should not try to change society to reflect God's will. Overall, about $72 \%$ of the churchgoing Protestants who believe that Christians should not try to change society to reflect God's will say it is because they should not be trying to impose their religion on American society.

Table 4.

Binary Logistic Regressions of The View That Christians Should Not Want To Try To Change The World

Because Christians Should Not Be Trying To Impose Their Religion On American Society

\begin{tabular}{|c|c|c|}
\hline & Model 1 & Model 2 \\
\hline Less Than High School & $-0.741(0.477)$ & $-1.121(0.326)$ \\
\hline (High School Reference) & -------- & -------- \\
\hline Vocational/Technical & $1.004(2.730)$ & $0.581(1.789)$ \\
\hline Some College & $0.330(1.390)$ & $0.304(1.356)$ \\
\hline College Graduate & $0.935(2.548)^{*}$ & $1.004(2.729)^{*}$ \\
\hline Any Graduate School & $1.474(4.368)^{* *}$ & $1.663(5.276)^{* *}$ \\
\hline Marital Status & -.--.--.- & $0.055(1.057)$ \\
\hline Children & -..--- & $0.677(1.968)$ \\
\hline Male & -----.--- & $-0.134(0.875)$ \\
\hline Age & -------- & $0.000(1.000)$ \\
\hline Father's Education & -..--..-- & $-0.023(0.978)$ \\
\hline Fundamentalist or Evangelical & --------- & $-0.086(0.917)$ \\
\hline Church Attendance & -------- & $-0.621(0.537)^{* *}$ \\
\hline Conservative Protestant & -------- & $0.568(1.765)$ \\
\hline African-American Protestant & --------- & $-0.262(0.769)$ \\
\hline $\begin{array}{l}\text { Other Protestant } \\
\text { (Mainline Protestant Reference) }\end{array}$ & --------- & $0.783(2.188)$ \\
\hline Constant & 0.431 & 1.783 \\
\hline Chi-Square & $16.640^{* *}$ & $31.234 * *$ \\
\hline-2 Log Likelihood & 266.377 & 251.783 \\
\hline $\begin{array}{l}+\mathrm{p} \leq .1 \quad * \mathrm{p} \leq .05 \\
\text { Odds ratios in parentheses } \\
\text { Models weighted by household size } \\
\mathrm{N}=229\end{array}$ & $\mathrm{p} \leq .001$ & \\
\hline
\end{tabular}


Regression results show that among churchgoing Protestants who believe Christians should not be trying to change society to reflect God's will, education positively affects the view that Christians should not try to change society because they should not impose their religion on society (Table 4). All else being equal, the odds for a college educated churchgoing Protestant saying Christians should not try to change society to reflect God's will because they should not impose their religion on society is more than two and two-thirds times larger than the odds for a high school graduate (Model 2). The effects of graduate school education are even larger. The odds for a churchgoing Protestant with any graduate school education reporting that Christians should not try to change society because they should not impose their religion on society is more than five times the odds for a high school graduate. In addition to the effects of education, church attendance has a fairly strong, negative effect on the view that Christians should not try to change society because they should not impose their religion on society. For instance, cross-tab results (not shown) indicate that $86 \%$ of Protestants who attend church only a few or many times a year say that Christians should not try to change society because they should not impose their religion on society, compared to $65 \%$ of Protestants who attend church at least weekly. While church attendance has a strong effect, it does not diminish the effects of education. In fact, college and graduate school education have stronger effects when the control variables are included in the model (compare models 1 and 2). Both models are fairly robust, considering the reduced sample size (significant Log Likelihood reduction from null model and fairly large Chi-Square statistics for small sample regressions). The findings from this third dependent variable support the suggestion that college and graduate school educated Protestants' distrust of highly politicized Christianity, which was demonstrated with the first two dependent variables, is at least partially due to their fear of imposing Christianity on secular society.

\section{DISCUSSION AND CONCLUSIONS}

I proposed that college and graduate school educated churchgoing Protestants are distrustful of highly politicized Christianity, particularly because they fear forcing the Christian religion on society. Measures from the Religious Identity and Influence survey support this proposition, demonstrating that churchgoing Protestants with a college or graduate school education are considerably less likely than those with only a high school education to say that Christian morality should be the law of the land. Highly educated churchgoing Protestants are also less likely to support Christians trying to change society to reflect God's will; and, among the churchgoing Protestants who say that Christians should not try to change society to reflect God's will, the highly educated are especially likely to say that they should not try to change society because they should not impose their religion on society. As a whole, highly educated churchgoing Protestants are somewhat skeptical of Christian organizations and Christian individuals attempting to change society and particularly the law to reflect Christian doctrines, at least partially due to their fear of imposing the Christian religion on others (and possibly on themselves). Moreover, the effects of education on views of politicized Christianity hold true for fundamentalist, evangelical, and mainline Protestants as well as for those who attend church more than once a week and those who attend less often. College and graduate school educated Protestants, regardless of their denominational affiliation or fundamentalist and evangelical identities, often prefer a more subdued role for Christianity in the political arena, in line with the privatized worldview that stresses the individual's rela- 
tionship with the supernatural rather than society's or an institution's relationship with the supernatural.

While the results support a somewhat privatized or individualistic approach to the Christian religion among highly educated churchgoing Protestants, they do not support a negative view of Christianity among highly educated churchgoing Protestants. College and graduate school educated churchgoing Protestants are at least somewhat supportive of the Christian religion since they identify themselves as Protestants and either attend church regularly or say faith is extremely important to their lives. Nevertheless, they support the privatization of Christianity in the sense that they tend to think the Christian religion should not be the basis of law and they fear forcing Christianity on other people. The privatized Christian may hold to many religious beliefs but he or she is often skeptical of the power of religious organizations. As Bellah and colleagues conclude (1985: 234), "Commoner among religious individualists than criticism of religious beliefs is criticism of institutional religion." Highly educated churchgoing Protestants appear skeptical of the power of Christian organizations in the political arena, but this does not mean they are disapproving of the Christian religion. In their discussion of different aspects of secularization, Stark and Finke (2000: 200) define desacralization as "the differentiation of religious and other primary social institutions." The above findings suggest that highly educated Protestants are generally supportive of desacralization or religion having little control over the state and other social institutions, but this does not mean they support other aspects of secularization. Highly educated churchgoing Protestants appear inclined to agree with Phillip Hammond (2000: 172) when he said, "religion's public authority is precisely what must be relinquished when religion engages in public debate."

The commitment to protecting civil liberties, the high appraisal of individualism, and the suspicion of others having authority over their lives probably contribute to college and graduate school educated Protestants' distrust of highly politicized Christianity by emphasizing the rights of the individual as opposed to powerful, politicized religious organizations. Highly educated churchgoing Protestants, with their emphasis on individual rights, are often wary of Christian organizations imposing themselves on society, especially on non-Christians. This is not meant to suggest that highly educated Protestants oppose Christian organizations or devout individuals taking any social and political stances, rather they are mistrustful of high levels of Christian politicization or political actions aimed at imposing Christianity on secular society.

The role of religion in the political arena, particularly in the 2004 presidential election, is making headlines across the country, with issués such as same-sex marriage, public funding of faith-based charities, and "under God" in the Pledge of Allegiance (Greenhouse 2004; Murphy 2004). As the media continually reminds us, the 2004 election was largely about "moral values." Political leaders from both the right and the left are pronouncing the importance of religion in their lives and in their decision-making-"secularism has become a dirty word" in politics (Jacoby 2004). The distrust of high levels of Christian politicization that is common among college and graduate school educated churchgoing Protestants, even among highly educated evangelical Protestants, may influence the future role of religion in the political arena. The average number of years of schooling in the U.S. rose from less than eight years in 1950 to more than twelve years in 2000 (Barro and Lee 2001). As larger segments of the population become college educated, public opinion on the relationship between religion and politics can change, thereby influencing the positions taken by politicians. In other 
words, with more Protestants going to college, secularism may not be such a dirty word in future U.S. elections.

\section{ACKNOWLEDGEMENTS}

Direct all Correspondence to Philip Schwadel, 711 Oldfather Hall, University of Nebraska, Lincoln, NE 685880324. E-mail: pschwade12@unl.edu. I would like to thank Amy Anderson, Roger Finke, Phil Jenkins, John McCarthy, Alan Sica, the editor of Review of Religious Research, and two anonymous reviewers for their suggestions and advice on earlier versions of this article.

\section{NOTES}

'I do not want to suggest that highly educated people do not accept any authority. In fact, some research suggests that the higher educated are more likely to accept "functionally necessary authority" related to achievement (Parsons and Platt 1970).

${ }^{2}$ Many thanks to Christian Smith for allowing me to use the RII data for this project.

${ }^{3}$ Randomly generated phone numbers, corresponding to the proportion of the national telephone exchanges in each region, are representative of all telephones in the contiguous United States. Non-household phone numbers were rejected from the sample. Interviewers asked to speak to the household member with the next birthday who is over seventeen years of age, ensuring a random sample of non-institutionalized adults. The response rate was $69 \%$.

${ }^{4}$ The denominational groupings are based on the coding supplied by Steensland and colleagues (2000), though I had to group additional denominations, those denominations not addressed by Steensland and colleagues, into religious categories.

${ }^{5}$ Church attendance is coded as follows: never (4 percent), few or many times a year ( 9 percent), 1 to 3 times a month ( 24 percent), and once a week or more (63 percent).

${ }^{6}$ Age is coded as years of age, male is a dummy variable for men, children is a dummy variable for having children, married is coded as married (1), widowed (2), divorced (3), separated (4), and never married (5), and father's education is coded as less than a high school degree (1), a high school degree (2), a vocational or technical degree (3), some college (4), a college degree (5), and any graduate school (6). A dummy variable for African-Americans is not included in the models due to its high colinearity with the dummy variable for affiliation with an AfricanAmerican Protestant denomination (correlation $=.719$ ).

\section{REFERENCES}

Audi, Robert and Nicholas Wolterstorff. 1997. Religion in the Public Square: The Place of Religious Convictions in Political Debate. Lanham, MD: Rowman \& Littlefield Publishers, Inc.

Beckford, James A. 1985. "Religious Organizations." In Phillip. E. Hammond, (ed.) The Sacred in a Secular Age: Toward Revision in the Scientific Study of Religion, pp. 125-138. Berkeley, CA: University of California Press.

Barro, Robert J. and Jong-Wha Lee. 2001. "International Data on Educational Attainment: Updates and Implications." Oxford Economic Papers 3: 541-563.

Bellah, Robert N., Richard Madsen, William M. Sullivan, Ann Swidler, and Steven M. Tipton. 1985. Habits of the Heart: Individualism and Commitment in American Life. NY: Harper \& Row, Publishers.

Beyer, Peter. 1994. Religion and Globalization: Theory, Culture, \& Society. London: Sage.

Billings, Dwight B. and Shaunna L. Scott. 1994. "Religion and Political Legitimation." Annual Review of Sociology 20:173-202.

Caplovitz, David and Fred Sherrow. 1977. The Religious Drop-Outs. Beverly Hills, CA: Sage.

Carter, Stephen. 1993. The Culture of Disbelief. New York: Basic Books.

Darlington, Richard B. 1990. Regression and Linear Models. New York: McGraw-Hill.

Dewey, John. 1959. "Progressive Education and the Science of Education." In Martin S. Dorkin (ed.) Dewey on Education, pp. 113-126. New York: Bureau of Publications, Teachers College, Columbia University.

Fox, William S., David E. Payne, Thomas B. Priest, and William W. Philliber. 1977. "Authority Position, Legitimacy of Authority Structure, and Acquiescence to Authority." Social Forces 55:4:966-973.

Gilbert, Dennis and Joseph A. Kahl. 1987. The American Class Structure: A New Synthesis. Chicago, IL: The Dorsey Press. 


\section{Education and Churchgoing Protestants'Views}

Greenhouse, Linda. 2004. “One Crucial Issue in Pledge Case: What Does ‘Under God' Mean?” New York Times, 22 March, national edition.

Greer, Bruce A. and Wade Clark Roof. 1992. “'Desperately Seeking Sheila:' Locating Religious Privatism in American Society.” Journal for the Scientific Study of Religion 31:3:346-352.

Hall, Robert, Mark Rodeghier, and Bert Useem. 1986. "Effects of Education on Attitude to Protest." American Sociological Review 51: 564-573.

Hammond, Phillip E. 2000. The Dynamics of Religious Organizations: The Extravasation of the Sacred and other Essays. Oxford: Oxford University Press.

Herman, Didi. 2001. "Globalism's 'Siren song': The United Nations and International Law in Christian Right Thought and Prophecy." The Sociological Review 77:56-77.

Jacoby, Susan. 2004. "One Nation, Under Secularism." New York Times, 8 January, national edition.

Kohn, Melvin L. and Carmi Schooler. 1969. "Class, Occupation, and Orientation." American Sociological Review 34: 659-678.

Menard, Scott. 1995. Applied Logistic Regression Analysis. Thousand Oaks, CA: Sage.

Murphy, Dean E. 2004. "San Francisco Married 4,037 Same-Sex Pairs From 46 States.” New York Times, 18 March, national edition.

Parsons, Talcott and Gerald M. Platt. 1970. “Age, Social Structure, and Socialization in Higher Education.” Sociology of Education 43:1:1-37.

Rawls, John. 1993. Political Liberalism. New York: Columbia University Press.

Regnerus, Mark and Christian Smith. 1998. "Selective Deprivation Among American Religious Traditions: The Reversal of the Great Reversal." Social Forces 76:4:1347-1372.

Robbins, Thomas. 1993. "The Intensification of Church-State Conflict in the United States." Social Compass 40:4:505-527.

Roof, Wade Clark and William McKinney. 1987. American Mainline Religion. New Brunswick, NJ: Rutgers University Press.

Smith, Christian. 1998. American Evangelicalism Embattled and Thriving. Chicago: University of Chicago Press.

Stark, Rodney and Roger Finke. 2000. Acts of Faith: Explaining the Human Side of Religion. Berkeley, CA: University of California Press.

Steensland, Brian, Jerry Z. Park, Mark D. Regnerus, Lynn D. Robinson, W. Bradford Wilcox, and Robert D. Woodberry. 2000. "The Measure of American Religion: Improving the State of the Art." Social Forces 79:1: 291318.

Sumner, Colin. 1997. "Social Control: the History and Politics of a Central Concept in Anglo-American Sociology." In Roberto Bergalli and Colin Sumner (eds.) Social Control and Political Order: European Perspectives at the End of the Century, pp. 1-35. Thousand Oaks, CA: Sage.

Wuthnow, Robert. 1988. The Restructuring of American Religion: Society and Faith Since World War II. Princeton, NJ: Princeton University Press. 